\title{
WOJNA HYBRYDOWA JAKO PRZEJAW NEOIMPERIALNEGO EKSPANSJONIZMU W STRATEGII POLITYCZNEJ FEDERACJI ROSYJSKIEJ WOBEC UKRAINY
}

\author{
Marcin Orzechowski \\ Instytut Politologii i Europeistyki \\ Uniwersytet Szczeciński \\ Wydział Humanistyczny, Uniwersytet Szczeciński \\ e-mail: orzechowski.martin@gmail.com
}

\begin{abstract}
Streszczenie: Tematem artykułu jest analiza specyfiki zjawiska wojny hybrydowej jako metody działania stosowanej w sytuacji konfliktowej pomiędzy dwoma podmiotami w stosunkach międzynarodowych. Strona dominująca w konflikcie, stosując elementy wojny hybrydowej chce przede wszystkim uzyskać względnie trwałą przewagę nad przeciwnikiem, w celu osiągnięcia określonej pozycji. W przypadku konfliktu we wschodniej Ukrainie strategicznym celem Federacji Rosyjskiej jest podkreślenie znaczenia tego państwa w przestrzeni poradzieckiej. Hybrydyzacja może zatem dotyczyć zarówno strony walczącej (państwa, aktora pozapaństwowego, nieregularnego ugrupowania zbrojnego), jak też przestrzeni konfliktu (zwłaszcza pola walki), jego genezy oraz natury, czyli tzw. ekosystemu konfliktu.
\end{abstract}

Słowa kluczowe: Federacja Rosyjska, Ukraina, konflikty międzynarodowe, wojny hybrydowe, bezpieczeństwo międzynarodowe

Początek XXI w. przyniósł dla Federacji Rosyjskiej wiele wyzwań, widocznych także w myśleniu strategicznym. Poszukiwanie nowych koncepcji, podyktowanych rosnącym dysonansem między ideami i działaniami realizowanym we wczesnym okresie postzimnowojennym a przezwyciężaniem kryzysów wewnętrznych, pogodzenie się z częściową utratą wpływów w Europie Środkowo-Wschodniej, wreszcie wizja rozszerzenia wpływów NATO i UE na obszar wschodnioeuropejski, doprowadziły do przewartościowań w koncepcjach strategicznych Rosji, w stosunku do całego obszaru poradzieckiego. Jeszcze w latach dziewięćdziesiątych ubiegłego stulecia zaczęto zarzucać Rosji podsycanie różnego rodzaju konfliktów, które towarzyszyły wspomnianemu już procesowi rozpadu ZSRR. Kreowanie i podtrzymywanie tych konfliktów stało się dla Rosji 
swoistym narzędziem, formą walki o wpływy i kontrolę poza granicami Federacji Rosyjskiej. Takie byłe republiki ZSRR, jak Gruzja, Mołdawia, Azerbejdżan podjęły próbę ustanowienia pełnej kontroli nad swoim terytorium. W pierwszej, zdecydowanie najgorętszej fazie konfliktów to właśnie Rosja odegrała kluczową i decydującą o przyszłości konfliktów rolę. ${ }^{1}$

Federacja Rosyjska w latach dziewięćdziesiątych zadeklarowała w sposób jednoznaczny chęć pełnienia roli „arbitra” i „gwaranta stabilności” w przestrzeni poradzieckiej. Wynikało to $\mathrm{m}$. in. z utożsamiania się rosyjskich decydentów politycznych ze stanowiskiem, iż położenie geograficzne jest w dalszym ciągu punktem wyjścia dla określenia strategicznych priorytetów, jakie mają dominować w koncepcjach i implementacji polityki zagranicznej państwa a rozmiar terytorialny pozostaje niezmiennie jednym z podstawowych mierników międzynarodowej pozycji i postrzegania przez innych uczestników stosunków międzynarodowych. ${ }^{2}$ Jednakże w przypadku konfliktu naddniestrzańskiego pojawiały się określenia definiujące go jako tzw. „konflikt niskiej intensywności”.

Nowa jakość w definiowaniu zjawiska „konfliktów niskiej intensywności” pojawiła się już po zakończeniu zimnej wojny wraz z tzw. ,nowym typem zorganizowanej przemocy", zachodzącym wewnątrz danego państwa. Charakterystycznymi cechami tego rodzaju konfliktów jest, oprócz wspomnianej już „lokalizacji”" we wnętrzu państwa, także występowanie tzw. „transnarodowych powiązań”, wyrażających się w postaci różnego rodzaju mediatorów, najemników, doradców i ekspertów, czynnie zaangażowanych w tego rodzaju spór, co w konsekwencji powoduje swoiste zacieranie się różnic $\mathrm{w}$,konfliktach niskiej intensywności” tego co lokalne z tym co posiada charakter globalny. ${ }^{3} \mathrm{Nie}$ bez znaczenia przy podejmowaniu tematyki „konfliktów niskiej intensywności” są uwarunkowania historyczne i to nie tylko te, odnoszące się do historii najnowszej, ale jak pokazuje przykład Mołdawii i Naddniestrza, również i te sięgające nieco dalej w przeszłość. ${ }^{4}$

Jak pisze M. Pietraś, pojęcie „konfliktu niskiej intensywności” (low intencity conflict) pojawiło się w naukach wojskowych w Stanach Zjednoczonych pod koniec lat siedemdziesiątych XX wieku. Służyło ono definiowaniu działań podjętych przez to państwo, skupiających się na poszukiwaniu skutecznego mechanizmu, który umożliwiłby prowadzenie działań o charakterze militarnym w państwach trzeciego świata. Jak zatem widać pierwotne definiowanie konfliktów niskiej intensywności miało wówczas jeszcze bardzo niewiele wspólnego z obecnym pojmowaniem tego, a wynikało przede wszystkim ze specyfiki bipolarnego sys-

1 F. Gołembski, Z. Szmyd, Mołdowa a Rosja, „Polityka Wschodnia” 1998, nr 1, s.50.

2 Zob. szerzej Z. Brzeziński, Wielka Szachownica. Główne cele polityki amerykańskiej, Warszawa 1997, s. 36-56 oraz 88-97.

3 Ibidem, s. 33-34.

4 Szerzej na temat konfliktu w Naddniestrzu: M. Orzechowski, Struktura interesów politycznych Rosji w Naddniestrzu i w regionie, [w:] Konflikt niskiej intensywności w Naddniestrzu, pod red. M. Celewicza, J. Kłoczowskiego, M. Pietrasia, Lublin 2006, s. 113-133. 
temu w stosunkach międzynarodowych. ${ }^{5}$ Decydenci i stratedzy polityczni Stanów Zjednoczonych określali w ten sposób działania o charakterze militarnym w państwach, które znajdowały się wówczas pod wpływem bloku wschodniego. ${ }^{6}$ Innym terminem, który również pojawił się w amerykańskiej terminologii specjalistycznej, dotyczącej określania sposobów prowadzenia działań zbrojnych była tzw. „wojna hybrydowa”. Jednym z czynników stymulujących pojawienie się nowego ,sposobu” na prowadzenie działań (nie tylko o charakterze militarnym) w relacji pomiędzy państwami była $\mathrm{m}$. in. swoista niemożność przezwyciężenia impasu, w jakim znalazła się współczesna sztuka wojenna na skutek rosnącej złożoności konfliktów oraz sposobów i metod ich rozstrzygnięcia. Chodziło przede wszystkim o to, że we współczesnych konfliktach ani wyższość technologiczna, ani doskonałość organizacyjna, ani nawet przewaga psychologiczna nie były elementami gwarantującymi osiągnięcie zwycięstwa. ${ }^{7}$

Etymologia terminu „hybrydowość” prowadzi do łacińskiego słowa hybryda, oznaczającego „mieszańca”, osobnika powstałego ze skrzyżowania dwóch genetycznie różnych osobników, należących do różnych gatunków, odmian czy ras. ${ }^{8}$ Uważa się, iż koncepcyjne ujęcie specyfiki wojen hybrydowych stanowi swoistą kontestację teorii dotyczących konfliktów pomiędzy podmiotami stosunków międzynarodowych takich jak teoria działań kontr partyzanckich, ,,wojna czwartej generacji”, , wojna postindustrialna”, ,globalna insurekcja”, ,strategiczny paraliż”

5 M. Pietraś, Istota i specyfika konfliktów niskiej intensywności [w:] ibidem, s. 24-25.

6 T.A. Marks, Counterinsurgency and operational art, „Low Intensity Conflict \& Law Enforcement", 2005 r., nr 3, s. 171-175.

7 A. Palazzo, A. Trentini, Hybrid, Complex, Conventional, Fourth-Generation Counterinsur-gency. It's Decision that Still Matters Most, „Australian Army Journal", 2010 r., nr 1, s. 72.

8 Zob. Slownik wyrazów obcych PWN, Warszawa 1980 r., s. 290. Por. Webster's New World Dictionary, wyd. 2, Prentice Hall Press, Nowy Jork 1986 r., s. 687.

9 Wojny pierwszej generacji prowadzone były aż do końca XIX w. Polegały one na starciu skoncentrowanych, potężnych mas ludzkich. Liczyła się liczebność, uzbrojenie, strategia i taktyka na polu bitwy. Wojna francusko-pruska zapoczątkowała okres wojen drugiej generacji - wojny $\mathrm{z}$ użyciem zmasowanych sił ognia - wojna pozycyjna z przesuwającą się w jedną, bądź drugą stronę linią frontu. Kulminacją tego okresu była I Wojna Światowa, ale klasyczny front zachował się jeszcze do drugiej połowy XX wieku. Wojna Koreańska była zmierzchem tego typu wojen a granica koreańsko-koreańska jest de facto linią frontu z 1953 roku. III generacja to wojny manewrowe - bez frontu, wykorzystująca przewagę technologiczną i logistyczną - punktowe akcje, której elementy pojawiły się podczas wojny Wietnamskiej, a której kulminacja przypada na okres operacji militarnej NATO w Kosowie - z chirurgiczną precyzją, naloty punktowe, kamery na każdej głowicy, naloty na konkretne punkty. Także wykorzystanie dronów - krążących po arabskim niebie, to elementy wojny III generacji. Wraz z atakami na WTC świat zaczął się zastanawiać nad klasyfikacją ,wojny z terroryzmem”, jak ją określono. Była zgoda co do tego, że to nowy typ wojny. Teoretycy wojskowości wyznaczyli kilka charakterystycznych cech wojny IV generacji, której kluczowym elementem jest zmiana celów. Celem przestały być obiekty fizyczne, ale ludzka świadomość. Wojny IV generacji mają rozgrywać się w ludzkiej świadomości. Aneksja Krymu wydaje się być dobrym przykładem na zjawisko wojny IV generacji. Formalnie wojska rosyjskie nie weszły na Krym, funkcjonująca tam tzw. „Samoobrona”, dysponująca środkami regularnej, dobrze wyposażonej i zorganizowanej armii nie ma oznaczeń pozwalających jej identyfikację. 
czy koncepcja konfliktów asymetrycznych. ${ }^{10}$ Kluczowe w tym przypadku wydaje się być założenie, że współczesne wojny nie są już grami o sumie zerowej, gdyż nie mogą się zakończyć całkowitym zwycięstwem którejkolwiek ze stron. ${ }^{11}$ Nawet ewidentny sukces militarny nie gwarantuje bowiem osiągnięcia celów i interesów $\mathrm{w}$ wymiarze strategicznym, politycznym i społecznym. ${ }^{12}$ Właśnie ta interpretacja specyfiki wojen hybrydowych skłaniała do postawienia tezy, że właśnie dlatego Federacja Rosyjska zastosowała wobec Ukrainy „strategię wojny hybrydowej”, gdyż zwiększała ona szansę na utrzymanie a nawet i wzmocnienie wpływów $\mathrm{w}$ tym państwie poprzez rozbicie integralności terytorialnej..$^{13}$

Generał Ben Hodges, dowódca wojsk amerykańskich w Europie powiedział, że Rosja opracowała model tzw. hybrydowej wojny, który z powodzeniem przetestowała na Krymie. Amerykański dowódca odwołuje się przy tym do innego uznanego w Stanach Zjednoczonych autorytetu, byłego oficera piechoty morskiej, obecnie pełniącego funkcję eksperta i analityka Departamentu Obrony USA, Franka G. Hoffmana, który wojnę hybrydową określa jako konfrontację, cechującą się ,zbieżnościa fizyczna i psychologiczna, kinetyczna i niekinetyczna, bojowników $i$ cywilów [...] sit zbrojnych $i$ spoteczności, państw i aktorów niepaństwowych, a także zdolności bojowych, $w$ które sa wyposażone". ${ }^{14}$ Według tego eksperta przyszłe zagrożenia mogą być w coraz większym stopniu charakteryzowane jako hybrydowa mieszanka tradycyjnych i nieregularnych taktyk. ${ }^{15}$ Mogą też być określone jako zdecentralizowane planowanie i wykonywanie również z udziałem podmiotów niepaństwowych, wykorzystujących zarówno proste, jak i złożone technologie. ${ }^{16}$ Frank G. Hoffman przytacza opinie innych ekspertów poruszają-

Rosja odwołała się do demokratycznych mechanizmów wyrażania woli społecznej jakim jest referendum. Niemniej jednak cała sytuacja wzbudziła wiele kontrowersji. „Aspekt świadomościowy” dotyczył wytworzenia opinii, że społeczność Krymu w zdecydowanej większości chce przyłączenia do Federacji Rosyjskiej a przeprowadzone referendum miało być tego potwierdzeniem. http:// www.wiadomosci24.pl/artykul/krym_wojna_iv_generacji_298475.html

${ }^{10}$ A. Gruszczak, Hybrydowość wspótczesnych wojen - analiza krytyczna [w:] Asymetria $i$ hybrydowość - stare armie wobec nowych konfliktów, pod red. W. Sokały i B. Zapały, s. 9-18., Adres URL artykułu: http://www.bbn.gov.pl/download/1/8755/Hybrydowos wspolczesnych wojen_analiza_krytyczna.pdf. [dostęp: 26.06.2015]. Adres URL monografii: http://www. bbn.gov.pl/download/1/8729/Asymetriaihybrydowoscstarearmiewobecnowychkonfliktow.pdf. [dostęp: 26.06.2015].

${ }^{11}$ N. Freier, The defense identity crisis: It's a hybrid world, „Parameters”, 2009 r., nr 3, s. $82-83$.

${ }^{12}$ D.T. Lasica, Strategic Implications of Hybrid War: A Theory of Victory, School of Advanced Military Studies, United Army Command and General Staff College Press, Fort Leavenworth 2009 r., s. 11-12.

${ }^{13}$ T.A. Marks, Counterinsurgency and operational art..., s. 180.

${ }^{14}$ F.G. Hoffman, Hybrid Warfare and Challenges, „Joint Force Quarterly", 2009 r., nr 52, s. 34 .

${ }^{15}$ Idem, Conflicts in the 21st Century: The Rise of Hybrid Wars, Potomac Institute for Policy Studies, Arlington 2007 r., s. 14.

${ }^{16}$ D.T. Lasica, op. cit., s.15-17. 
cych w swych analizach problematykę dotyczącą zjawiska wojny hybrydowej. Według D.T. Lasicy, hybrydowość to logiczna kombinacja strategii i taktyki zmierzająca do wymieszania różnych typów działań zbrojnych. ${ }^{17}$ R.G. Walker traktuje hybrydowość jako wynik konwergencji zasad wojny konwencjonalnej i operacji specjalnych. ${ }^{18} \mathrm{Z}$ kolei J.J. McCuen ujmuje hybrydowość jako kombinację wojny symetrycznej i asymetrycznej. ${ }^{19} \mathrm{~N}$. Freier pisze natomiast o powiązaniu trzech źródeł ryzyka i nieprzewidywalnych wydarzeń: działań nieregularnych (partyzanckich), tradycyjnych konfliktów (w ograniczonym zakresie) oraz najpoważniejszych (high-end) zagrożeń asymetrycznych. ${ }^{20}$

Z przytoczonych wyżej definicji wynika jednoznacznie, że strona dominująca w konflikcie, stosując elementy wojny hybrydowej chce przede wszystkim uzyskać względnie trwałą przewagę nad przeciwnikiem, w celu osiągnięcia strukturalnej transformacji przestrzeni konfrontacji, m. in. mogącej się przejawiać w zwiększeniu skali oddziaływania konfliktu na środowisko lokalne i międzynarodowe. ${ }^{21}$ Owo zwiększenie skali oddziaływania może być wykorzystana jako swoista ,karta przetargowa”, np. w działaniach mediacyjnych a w przypadku Federacji Rosyjskiej do podkreślenia znaczenia tego państwa w przestrzeni postradzieckiej. Hybrydyzacja może zatem dotyczyć zarówno strony walczącej (państwa, aktora pozapaństwowego, nieregularnego ugrupowania zbrojnego), jak też przestrzeni konfliktu (zwłaszcza pola walki), jego genezy oraz natury, czyli tzw. ekosystemu konfliktu). ${ }^{22}$

W odniesieniu do współczesnych konfliktów zbrojnych hybrydyzacja może być rozumiana jako współistnienie elementów „starych” i „nowych” wojen, klasycznych konfliktów zbrojnych i wojen ,ponowoczesnych”, starcia narodowych armii i konfliktów asymetrycznych, supertechnologii wojskowych i prymitywnych broni, walki o terytoria i zasoby oraz sporów o tożsamość i wartości, konfrontacji zaściankowości i kosmopolityzmu. ${ }^{23}$

Strategia prowadzenia wojny hybrydowej zawiera szereg różnych sposobów prowadzenia działań o charakterze militarnym, zarówno z wykorzystaniem standardowego uzbrojenia, taktyki i nieregularnych formacji, jak również w skrajnych przypadkach stosowania aktów terrorystycznych (w tym przemocy i przymusu). ${ }^{24}$ Wojny hybrydowe mogą być prowadzone zarówno przez państwa, jak i podmioty,

${ }^{17}$ D.T. Lasica, op. cit., s. 11.

${ }^{18}$ R.G. Walker, SPEC FI: The United States Marine Corps and Special Operations, Storming Media, Monterrey 1998 r., s. 4-5.

${ }^{19}$ J.J. Mc Cuen, Hybrid Wars, „Military Review”, 2008 r., nr 2, s. 108.

${ }^{20}$ N. Freier, Hybrid threats and challenges: describe [...] don 't define, „Small Wars Journal”, http://www.smallwarsjournal.com/blog/journal/docs-temp/343-freier.pdf [dostęp: 28.06.2015].

${ }^{21}$ D.T. Lasica, op. cit., s.26-30.

${ }^{22}$ A. Palazzo, A. Trentini, op. cit., s. 75 i nast.

${ }^{23}$ A. Gruszczak, op. cit., s. 10.

${ }^{24} \mathrm{~J}$. Robb, Brave New War. The Next Stage of Terrorism and the End of Globalization, Wiley, Hoboken 2007 r., s. 152-164. 
które nie posiadają statusu państwowego. W czasie takich konfliktów przeciwnicy (państwa, grupy podmioty państwowe sponsorowane lub finansujące własne działania) starają się korzystać z dostępu do nowoczesnych rozwiązań wojskowych, w tym szyfrowanych systemów dowodzenia, wspierać organizacje przedłużające wojnę partyzancką (jak to ma miejsce w przypadku prorosyjskich separatystów z Donbasu), które wykorzystują zasadzki, improwizowane urządzenia wybuchowe i morderstwa. ${ }^{25} \mathrm{Z}$ innych instrumentów możliwych do zastosowania należy wymienić także możliwość wykorzystania zaawansowanych technologicznie możliwości, takich jak cyberwojna finansowa, które operacyjnie i taktycznie ukierunkowane i koordynowane są w celu osiągnięcia synergii w wymiarach fizycznych i psychicznych konfliktu. ${ }^{26}$

Zdaniem A. Gruszczaka hybrydowość jest właściwością powstałą w wyniku skrzyżowania lub zmieszania cech, elementów należących do różnych, często odmiennych strukturalnie i odległych genetycznie, przeciwstawnych przedmiotów, organizmów lub stanów. Hybrydyzacja oznacza więc scalenie odmiennych istotowo cech wokół jednego, odrębnego bytu, przy zachowaniu specyficznych własności gatunkowych decydujących o „wyższości” nowego, hybrydowego organizmu pod względem np. odporności na choroby, wytrzymałości czy większych zdolności adaptacyjnych. ${ }^{27}$

W przypadku konfliktu na wschodniej Ukrainie mamy do czynienia z płaszczyzną terytorialną wojny hybrydowej - odnoszącą się do klasycznie rozumianego państwa narodowego oraz tradycyjnych wspólnot etnicznych, klanowych lub plemiennych stale zamieszkujących dane terytorium. Głównym celem wojny prowadzonej na płaszczyźnie terytorialnej jest rozciągnięcie i utrzymanie jurysdykcji oraz kontroli administracyjnej na danym obszarze, ochronę granic wyznaczających zasięg tej jurysdykcji, egzekwowanie zasad ustrojowych i norm prawnych w stosunku do ludności zamieszkującej ten obszar, zapewnienie ładu publicznego, zarządzanie zasobami naturalnymi i działalnością gospodarczą. ${ }^{28}$ Wojny w wymiarze wirtualnym redefiniują parametry konfliktu, a nawet eliminują niektóre determinanty, takie jak terytorium, zasoby naturalne, organizacja wojskowa, porządek publiczny. ${ }^{29}$

Jednakże, jak pisze m. in. przytaczany już kilkakrotnie A. Gruszczak w tego rodzaju konfliktach mamy do czynienia także z tzw. płaszczyzną wirtualną, gdzie mogą powstawać, tzw „pseudopaństwa” pozbawione tradycyjnych elementów władzy państwowej, podmiotowości prawnomiędzynarodowej i hierarchicznej organizacji, a jednak dysponujące skutecznymi instrumentami i metodami oddzia-

${ }^{25}$ M. Kaldor, New \& Old Wars: Organized Violence in a Global Era, Stanford University Press, 2001 r., s. 5-10;

${ }^{26}$ D.T. Lasica, op. cit., s.38.

${ }^{27}$ A. Gruszczak, op. cit., s. 10-11.

${ }^{28}$ Za przykład tego rodzaju działań uznawana jest separatystyczna Republika Naddniestrzańska - przyp. Aut.

${ }^{29}$ J.J. McCuen, op. cit., s. 110. 
ływania na środowisko międzynarodowe, wpływem na populację, pomnażaniem zasobów finansowych i prowadzenia kampanii informacyjnej..$^{30} \mathrm{~W}$ przypadku konfliktu na Ukrainie mamy do czynienia ze swoistym „dualizmem hybrydowym” bowiem możemy zaobserwować występowanie zarówno elementów charakterystycznych dla płaszczyzny terytorialnej, jak i wirtualnej. Z jednej strony powstanie Donieckiej Republiki Ludowej i Ługańskiej Republiki Ludowej ma być wyrazem wspomnianego wyżej zapewnienia ładu publicznego a uchwalone konstytucje obu republik mają pełnić rolę nadrzędnych aktów normatywnych mających na celu, egzekwowanie zasad ustrojowych i norm prawnych w stosunku do ludności zamieszkującej ten obszar. ${ }^{31} \mathrm{Z}$ drugiej strony zaś należy pamiętać, że są to podmioty nieuznawane przez społeczność międzynarodową, zasadne jest zatem używanie w stosunku do nich określenia ,pseudopaństwa”.

Część analityków i ekspertów cytowanych wyżej, w swych rozważaniach odwołuje się także do innego rozumienia pojęcia „hybrydowości”. Zjawisko to można analizować również jako rodzaj koadaptacji i konwergencji, czyli połączenia funkcjonalnych elementów dwóch odmiennych systemów. ${ }^{32}$ Konwergencja to zbieżność systemowa umożliwiająca postępujące, stopniowe i celowe niwelowanie różnic na rzecz ukształtowania uniwersalnego wzorca „organizacji różnorodności”. $\mathrm{W}$ odniesieniu do zagadnień bezpieczeństwa, konwergencja oznacza integrowanie fizycznych, logicznych, informacyjnych i osobowych zasobów w celu poprawy efektywności oraz operacyjnej skuteczności podmiotów odpowiedzialnych za przeciwdziałanie i zwalczanie zagrożeń oraz zarządzanie ryzykiem. ${ }^{33}$

Zdaniem A. Gruszczaka właśnie taki sposób interpretacji hybrydowości różni się znacząco od źródłowego pojęcia minimalizując różnice między uczestnikami konfliktu dotyczące $m$. in. stosowania instrumentów walki zbrojnej i operacji pozamilitarnych. $Z$ tego powodu należy zwrócić uwagę na kilka cech współczesnych wojen, które określają ich hybrydową naturę w odmienny sposób, niż koncepcja hybrydowości jako zbieżności wybranych parametrów konfliktu. ${ }^{34}$

W przypadku działań podejmowanych przez Federację Rosyjską na obszarze postradzieckim podejrzenia o stosowanie elementów charakterystycznych dla wojny hybrydowej pojawiają się nie po raz pierwszy. Przytaczany już kilkakrotnie F. G. Hoffman w jednym ze swoich artykułów wręcz oskarża Rosję, że w 2008 r. w Gruzji zostały zastosowane metody hybrydowej wojny. Pisał on. m. in., że jego

${ }^{30}$ D.J. Kilcullen, Counterinsurgency, Oxford University Press, Nowy Jork 2010 r., s. 200-202.

${ }^{31}$ Konstytucja Donieckoj Narodnoj Riespubliki, https://web.archive.org/web/201408302 21524/http://dnr.today/wp-content/uploads/2014/08/aeAEI.pdf [dokument w wersji PDF, dostęp: 12.03.2015]; zob. także: Wriemiennyj osnownyj zakon (Konstytucja) Ługańskoj Narodnoj Riespubliki, https://archive.is/BbQdc [dokument w wersji PDF, dostęp: 12.03.2015].

${ }^{32}$ Zob. Polska $w$ drodze do globalnego społeczeństwa informacyjnego. Raport o rozwoju społecznym, Program Narodów Zjednoczonych do spraw Rozwoju, Warszawa 2002 r., s. 89.

${ }^{33}$ Zob. D. Tyson, Security Convergence. Managing Enterprise Security Risk, Butterworth-Heinemann, Burlington 2007 r., s. 4.

${ }^{34}$ A. Gruszczak, op. cit., s. 15-16. 
własna definicja strategii obrony narodowej skupia się na rodzajach konfliktów przeciwnika ale obejmuje również działania o charakterze przestępczym: „Wielu teoretyków wojskowych unika tego elementu i nie chce mieć do czynienia z czymś, co nasza kultura gwaltownie odrzuca i wskazuje, że jest to aspekt, do którego rozwiazania sa uprawnione tylko organy ścigania". ${ }^{35}$

W przypadku konfliktu na Ukrainie mamy do czynienia z wojną formalnie niewypowiedzianą a prowadzone działania są swoistą mieszanką metod klasycznie militarnych - przede wszystkim nieregularnych działań zbrojnych (partyzantka, sabotaż, dywersja, akty terrorystyczne) - ale też pojawiają się elementy walki informacyjnej (propaganda, dezinformacja), ekonomicznej oraz cybernetycznej. ${ }^{36}$

Pojęcie wojny hybrydowej zyskało szczególnie na popularności w kontekście klasyfikowania „dziwnej wojny”, która rozpoczęła się w wyniku agresji Federacji Rosyjskiej na dwa wschodnie regiony Ukrainy. „Dziwna wojna” tocząca się w obwodach Ługańskim i Donieckim na wschodnich rubieżach Ukrainy jest formą niekonwencjonalnego konfliktu, w którym jedna ze stron oficjalnie nie ogłosiła stanu wojny, jednakże doniesienia obszarów objętych działaniami militarnymi jednoznacznie wskazują na to, kto jest w niej agresorem. ${ }^{37}$

Jak pokazuje sytuacja na Ukrainie, konflikt noszący znamiona wojny hybrydowej może przybrać bardziej subtelną formę, jak np. działania publicystów (propaganda rozpowszechniana przez sieć sponsorowanych przez Kreml portali medialnych w krajach Europy Zachodniej „Sputnik”) lub bardziej ewidentne jak blokada ekonomiczna (embargo na ukraińskie produkty czekoladowe). ${ }^{38}$ Wojna hybrydowa w takim wydaniu może przybierać również formę wywrotowych operacji wywiadowczych (inwigilacja lub wpływ na działania rządu), sabotaż, ataki hakerów na infrastrukturę informatyczną kraju lub działania zastępczych grup partyzanckich. ${ }^{39}$ Jednakże w zamierzeniu Rosji jednym z głównych celów w tym konflikcie pozostaje wywarcie wpływu na populację i decydentów politycznych poprzez nieoficjalne działania, celem uniknięcia oficjalnego zaklasyfikowania napaści. ${ }^{40}$ Strategię działań Federacji Rosyjskiej wobec Ukrainy cechuje wie-

${ }^{35}$ F.G. Hoffman, Hybrid Warfare and Challenges..., s. 36.

${ }^{36}$ Zob. szerzej: S. Bachman, H. Gunneriusson, Terrorism and Cyber Attacks as Hybrid Threats: Defining a Comprehensive Approach for Countering $21^{\text {st }}$ Century Threats to Global Peace and Security, [w:] "The Journal on Terrorism and Security Analysys", Spring 2014, $9^{\text {th }}$ Edition, s. 2-11; http://eprints.bournemouth.ac.uk/21206/1/Terrorism_and_Cyber_Attacks.pdf [artykułw wersji PDF, dostęp: 29.06.2015].

${ }^{37}$ Gibridnaja wajna Rossiji protiw Ukrainy, http://korrespondent.net/world/worldabus/ 3521538-hybrydnaia-voina-rossyy-protyv-ukrayny-Economist [dostęp: 30.05.2015].

${ }^{38}$ Ibidem.

${ }^{39}$ N. Popescu, Hybrid war: Neither new nor Russian, http://blogs.euobserver.com/popescu /2015/02/03/hybrid-war-neither-new-nor-russian [dostęp: 11.01.2015].

${ }^{40}$ P. Pindják, Deterring hybrid warfare: a chance for NATO and the EU to work together? http://www.nato.int/docu/review/2014/Also-in-2014/Deterring-hybrid-warfare/EN/index.htm [dostęp: 14.01.2015]. 
lowymiarowość - niszczenie przeciwnika na wielu płaszczyznach - militarnej, ekonomicznej, politycznej, informacyjnej oraz tożsamościowej.

Ambasador Stanów Zjednoczonych przy NATO Kurt Volker wyraził opinię, że kryzys przekracza daleko granice Ukrainy, a poglądy prezydenta Putina sprowadzają się do tego, że obrona etnicznych Rosjan nie leży w gestii państw, w których oni mieszkają, i nie podlega ich prawom, rządowi, czy konstytucji, ale podlega Rosji. ${ }^{41}$ To podejście prezydenta Rosji wobec etnicznych Rosjan, które wg tego eksperta jest nie tylko ,wyłomem w pojmowaniu prawa międzynarodowego", ale też techniką wojny hybrydowej, nazywaną ,nowym podejściem” w rosyjskiej strategii politycznej. „Myślę, że koncepcja powolnych wysilków, powolnego naruszania suwerenności jest częścia strategicznego krajobrazu dobrze znanego Rosji już od pewnego czasu” ocenia ekspert NATO. I dodaje: „Czasem obejmuje to bardziej otwarte i oczywiste posunięcia, czasem posunięcia sa bardziej subtelne, jest to walka za pomoca ekonomii, czasami - ataków cybernetycznych przeprowadzanych pod pozorem działań niezależnych aktywistów". Jego zdaniem taki „właśnie zbiór taktyk” wojny hybrydowej używa Rosja od co najmniej 5-6 lat. Powołując się na doświadczenia historyczne Kurt Volker sugeruje, że Rosja od bardzo dawna używa przez wywiad wojskowy i siły specjalne tzw. agentów-prowodyrów, których głównym zadaniem jest „destabilizowanie, paraliżowanie administracji, tworzenie przestrzeni do wywierania wplywów [...] Rosja będzie stosować operacje specjalne oraz wykorzystywać wywiad, presję ekonomiczna, presję energetyczna, ataki cybernetyczne oraz potencjat sit konwencjonalnych bezpośrednio do realizacji celów imperialnych". ${ }^{42}$

$\mathrm{W}$ ostatnich latach hakerzy zaczęli prowadzić wirtualne akcje dywersyjne nie tylko celem demonstracji swoich zdolności, ale także na zlecenie państw przeciwko innym państwom. ${ }^{43}$ Rosyjscy hakerzy bardzo szybko podjęli próby destabilizacji systemów teleinformatycznych Ukrainy. Na serwerach administracji rządowej w czerwcu 2014 roku znaleziono wirusa „Snake”, który prawdopodobnie posłużył do szpiegowania i zaburzania systemów informatycznych ${ }^{44}$ Rosyjski

${ }^{41}$ Putin wiediot w Ukrainie gibridnoju wajnu, http://ipress.ua/ru/mainmedia/putyn_vedet_v_ ukrayne_gybrydnuyu_voynu_61876.html [dostęp: 05.04.2015].

${ }^{42}$ Cyt. za: S. Klimowskij, Gibridnaja wajna w Ukrainie kak prolog globalnoj wajny, http:/hvylya. net/analytics/geopolitics/gibridnaya-voyna-kak-prolog-globalnoy-voynyi.html [dostęp: 06.04.2015].

${ }^{43}$ Według amerykańskiego Departamentu Obrony cyberterroryzmem jest bezprawny atak lub groźba takiego ataku przeciwko komputerom, sieciom komputerowym lub informacjom przechowanym na nich mający na celu zastraszenie lub wymuszenie na społeczeństwie lub rządzie danego kraju spełnienia określonych celów politycznych. W 2007 roku estoński system bankowy padł ofiarą cyberataku w ramach zemsty za usunięcie pomnika radzieckiego żołnierza w jednym z estońskich miast. Zanim pierwsze czołgi wjechały do Gruzji w 2008 roku, rosyjscy hakerzy zaatakowali strony gruzińskiej administracji - zob. szerzej: G. Weimann, Cyberterrorism, How Real Is the Threat? http://www.usip.org/sites/default/files/sr119.pdf [odczyt 02.02.2015].

${ }^{44}$ P. Górecki, Cyberatak na Ukrainę. Trudno będzie udowodnić, że to Rosja http://wyborcza.pl/1,75477,15614511,Cyberatak_na_Ukraine_Trudno_bedzie_udowodnic_ze.html [odczyt: 17.01.2015]. 
wirus szpiegowski zaatakował 84 strony administracji publicznej, w tym strony premiera Ukrainy, przemysłu obronnego i służby dyplomatycznej. ${ }^{45}$ Miesiąc wcześniej, w dniu majowych wyborów prezydenckich, Rosjanie przeprowadzili hakerski atak na strony Centralnej Komisji Wyborczej. Celem tej akcji, za którym stał tzw. „CyberBerkut” ${ }^{\text {”6 }}$ było usunięcie rezultatu wyborów i tym samym zdestabilizowanie sytuacji w kraju w dniu wyborów prezydenckich. Za kilka mniejszych ataków odpowiedzialny jest rosyjski cyber-gang „Quedagh” używający narzędzia do cyberprzestępstw zwanego Black Energy. ${ }^{47}$ Cyber-wojna może mieć także lżejszy wymiar, jak np. ta, którą opisał Infosec Institute. Według tego ośrodka badawczego, Rosjanie rekrutują i ćwiczą tzw. „nową armię trolli internetowych”, którzy mają za zadanie zmienić społeczne postrzeganie inwazji na Ukrainę, m. in. poprzez umieszczanie na blogach internetowych oraz na stronach medialnych świata zachodniego odpowiednio przygotowywanych wcześniej treści popierających działania Rosji i oczerniających Ukrainę oraz jej sojuszników. ${ }^{48}$

Stosunkowo łatwym zadaniem dla administracji rządowej było przekonanie obywateli Rosji co do słuszności inwazji na Ukrainę nie było trudnym zadaniem dla Kremla. Chcąc jednak zlegitymizować rosyjskie działania na Ukrainie wśród jak najszerszej międzynarodowej opinii publicznej, zastosowano szeroko zakrojoną kampanię informacyjną, której wspólnym mianownikiem stała się platforma medialna „Sputnik”. Serwis ten zarządzany przez rosyjską agencję Rossija Siegodnia działa już w 14 krajach, w tym od niedawna w Polsce. ${ }^{49}$ Jak podaje strona projektu Sputnik, „ukazuje wielobiegunowy świat, w którym każde państwo ma swoje narodowe interesy, kulturę, historię i tradycję". ${ }^{50}$

Narracja prezentowana przez platformę Sputnik opiera się na przedstawieniu Rosji jako wyzwoliciela i ostoi demokracji, ofiary zachodniego spisku mającego doprowadzić obywateli Rosji na skraj ubóstwa - przy jednoczesnym oczernianiu Unii Europejskiej, Ukrainy oraz Stanów Zjednoczonych. ${ }^{51}$ Same tytuły artykułów

${ }^{45}$ S. Jones, Ukraine PM's office hit by cyber attack linked to Russia http://www.ft.com/cms/ s/0/2352681e-1e55-11e4-9513-00144feabdc0.html\#axzz3S13skQKn [odczyt: 16.12.2014].

${ }^{46}$ CyberBerkut to organizacja zrzeszająca prorosyjskich hakerów I haktywistów specjalizujących się w przeprowadzaniu cyberataków na serwery ukraińskiej administracji rządowej - zob. http://cyber-berkut.org/en/

${ }^{47}$ D. Gilbert, BlackEnergy Cyber Attacks Against Ukrainian Government Linked to Russia http://www.ibtimes.co.uk/blackenergy-cyber-attacks-against-ukrainian-government-linked-russia-1467401 [odczyt: 03.05.2015].

${ }^{48}$ Russia and Ukraine: Information warfare, http://resources.infosecinstitute.com/russia-ukraine-information-warfare/ [dostęp:27.02.2015].

${ }^{49} \mathrm{M}$. Kowalczyk, Sputnik ruszył z rosyjską propagandą po polsku, http://www.press.pl/newsy/internet/pokaz/48006,Sputnik-ruszyl-z-rosyjska-propaganda-po-polsku [dostęp 17.11.2014].

${ }^{50}$ Sputnik, o projekcie, http://pl.sputniknews.com///docs/about/index.html\#ixzz3SrQTLf50 [dostęp: 03.12.2014].

${ }^{51}$ Jedną z ciekawszych hipotez, jaka pojawiła się na stronach tej platformy była ta mówiąca o tym, że konflikt na Ukrainie jest wynikiem polsko-amerykańskiego spisku sił wywiadowczych, który wymknął się spod kontroli po zorganizowaniu zamachu stanu na administrację prezydenta Wiktora Janukowycza - M. Kowalczyk, op. cit. 
prezentowanych przez wspomnianą platformę, w sposób niezwykle sugestywny obrazują rozmiary propagandy oraz przeinaczeń w sposobie prezentowania bieżących wydarzeń w stosunkach międzynarodowych, szczególnie tych mających jakikolwiek związek z konfliktem rosyjsko-ukraińskim. ${ }^{52}$ Politycy europejscy przedstawiani są jako niekompetentni, skorumpowani technokraci, opisywane są ich słabości, wyrwane z kontekstu wypowiedzi. Perspektywa ta wpisuje się w opinię zamordowanego rosyjskiego opozycjonisty Borysa Niemcowa, który przy opisywaniu masowej propagandy użył słów Goebbelsa ,im większe kłamstwo, tym lepsze; i kłamstwo należy powtarzać wiele razy". ${ }^{53}$

Na przykładzie działań zbrojnych na Ukrainie można stwierdzić, że aktywność „zielonych ludzików” wpisuje się w kryteria wojny hybrydowej. Początkowym symbolem wspomnianych wyżej „grup opozycyjnych” były własnie „,zielone ludziki" na Krymie. Żołnierze w mundurach, uzbrojeni niczym regularna armia, ale bez żadnych oznaczeń mogących zidentyfikować ich przynależność. Rosja przez dłuższy czas kategorycznie zaprzeczała, że ma z nimi coś wspólnego i dopiero po oficjalnej aneksji półwyspu prezydent Władimir Putin przyznał, że to byli rosyjscy żołnierze. Ekspert wileńskiego Instytutu Stosunków Międzynarodowych Margarita Seselgyte udowadnia, iż żołnierze rosyjscy stosują regularne i nieregularne sposoby prowadzenia wojny, część z nich powiązana jest z grupami kryminalnymi, ich umundurowanie nie jest jednolite ani oznaczone oraz działają w sytuacji, w której wojna nie została oficjalnie wypowiedziana. ${ }^{54} \mathrm{Z}$ kolei według analityków portalu IHS, obecnie na terytorium Ukrainy znajduje się 14 400 żołnierzy rosyjskich, wspierających 29300 nielegalnie zorganizowanych formacji separatystycznych na wschodniej Ukrainie. Ponadto 29400 rosyjskich żołnierzy stacjonuje na Krymie oraz kolejnych 55800 rozmieszczony wzdłuż granicy rosyjsko-ukraińskiej. ${ }^{55}$

Jak już wielokrotnie podkreślano konflikt w Donbasie i aneksję Krymu specjaliści okrzyknęli „,wojną XXI wieku” czy też, używając terminologii bardziej naukowej „wojną hybrydową". Co do jej charakterystyki, niemal wszyscy się zgadzają. Więcej

${ }^{52}$ J. Romanienko, Pierwaja gibridnaja. Kagda Rossija naczała wajnu protiw Ukraini, http:// hvylya.net/analytics/politics/pervaya-gibridnaya-kogda-rossiya-nachala-voynu-protiv-ukrainyi. html [dostęp: 17.04.2015].

${ }^{53}$ Faszyzm po rosyjsku, rozmowa Michała Kacewicza z Borysem Niemcowem, „Newsweek”, nr 10/2015; zob. także: K. Jarzyńska, „Raport Niemcowa” - zbiór dowodów udziału Rosji w wojnie na Ukrainie, Analizy OSW, 2015.03.05; http://www.osw.waw.pl/pl/publikacje/analizy/2015-05-13/ raport-niemcowa-zbior-dowodow-udzialu-rosji-w-wojnie-na-ukrainie [dostęp: 21.06.2015]; por. także: D. Sharkov, Nemtsov's ,Evidence of Russian Troops in Ukraine' Taken by Police, http:// www.newsweek.com/nemtsovs-evidence-russian-troops-ukraine-taken-police-310997 [dostęp: 11.12.2014].

${ }^{54}$ M. Seselgyte, Can Hybrid War Become the Main Security Challenge for Eastern Europe?, dostępny pod adresem: http://www.europeanleadershipnetwork.org/can-hybrid-war-become-themain-security-challenge-for-eastern-europe_2025.html [dostęp: 20.01.2015].

${ }^{55}$ R. F Johnson, UPDATE: Russia's hybrid war in Ukraine, is working'http://www.janes. com/article/49469/update-russia-s-hybrid-war-in-ukraine-is-working [dostęp: 03.03.2015]. 
sporów i kontrowersji budzi natomiast dylemat, czy działania Rosji były spontaniczne, podejmowane w sposób szybki i nie do końca przemyślany, czy wręcz przeciwnie, wszystkie decyzje i podjęte kroki praktyczne były zaplanowane. Pomocna w rozstrzygnięciu powyższego dylematu wydaje się być analiza wystąpienia szefa Sztabu Generalnego FR generała Walerija Gierasimowa za tym drugim wariantem.

Podczas wystąpienia na posiedzeniu członków Akademii Nauk Wojskowych 26 stycznia 2013 roku zatytułowanego: „Rola Sztabu Generalnego w organizacji obrony kraju w związku z nowym Statutem Sztabu Generalnego zatwierdzonym przez prezydenta Federacji Rosyjskiej”. ${ }^{56}$ Ów swoisty wykład generała był de facto wykładnią poglądów dowództwa rosyjskiego wojska na prowadzenie wojny nowego rodzaju. Chodziło o specyficzny rodzaj konfliktu, w którym zanikają różnice między wojną a pokojem w klasycznym rozumieniu tych słów oraz pomiędzy umundurowanym wojskiem a działaniami prowadzonymi pod przykryciem. Zdaniem W. Gierasimowa konflikt rozgrywany w ten sposób ma potencjał zmiany „całkowicie stabilnego kraju w arenę najbardziej intensywnego konfliktu zbrojnego w parę miesięcy, a nawet dni". ${ }^{57}$ Rosyjski generał nie ukrywał, że w polityce Rosji, szczególnie na obszarze postradzieckim w ostatnich latach nastąpiła znacząca tendencja zwyżkowa do wykorzystywania niemilitarnych środków w celu osiągnięcia politycznych i strategicznych zamierzeń, co może stać się ,znacząco bardziej efektywne niz klasyczne metody militarne. Szerokie zastosowanie maja dziatania asymetryczne, pozwalajace niwelować przewage przeciwnika w walce zbrojnej. Do nich zalicza się wykorzystanie sił operacji specjalnych $i$ wewnętrznej opozycji dla stworzenia stale działajacego frontu na catym terytorium wrogiego państwa, a także informacyjne oddziatywanie, formy i sposoby którego stale sie zmieniaja. Frontowe starcie duzych wojskowych formacji stopniowo odchodzi $w$ przeszłość", w wojnach nowego typu wymieszane sa szerokiego zakresu polityczne, ekonomiczne, informacyjne, humanitarne i inne metody". 58

Szef Sztabu Generalnego mówił też o asymetrycznych metodach walki, takich jak ograniczone użycie sił specjalnych oraz rekrutacja i mobilizacja grup opozycyjnych na terytorium wroga. Trudno nie zauważyć stosowania obu tych metod na wielką skalę na terytorium Ukrainy. I o ile dywersyjno-szpiegowskie akcje grup komandosów można uznać za typowe także dla wielu innych konfliktów na świecie, to już wspomniana „rekrutacja i mobilizacja grup opozycyjnych” jest

${ }^{56}$ Zob. szerzej: Rol gienieralnawo sztaba $w$ organizacji oborony strany $w$ sootwietstwi z nowym Położenijem o Gienieralnawom Sztabie utwierżdjonnym Priezidentom Rossijskoj Fiedieracyi, http://www.avnrf.ru/index.php/vse-novosti-sajta/620-rol-generalnogo-shtaba-v-organizatsii-oborony-strany-v-sootvetstvii-s-novym-polozheniem-o-generalnom-shtabe-utverzhdjonnym-prezidentom-rossijskoj-federatsii [odczyt: 14.01.2015].

${ }^{57} \mathrm{~W}$. Gierasimow, Ciennost nauki i priedwidienji. Nowyje wyzowy triebujut pierieosmyslenja form i sposobow wiedienja bojewych diejstwij, „Wojenno-promyszliewyj Kurier”, nr 8 94760, 27 fiewralia-5 marta 2013 goda, s. 2 i nast.; http://vpk-news.ru/sites/default/files/pdf/VPK_08_476. pdf [odczyt:16.01.2015].

${ }^{58}$ Cyt. za: Rol gienieralnawo sztaba w organizacji oborony strany... 
niczym innym, jak tworzeniem zbrojnych oddziałów samozwańczych Ludowych Republik Donieckiej i Ługańskiej. Potwierdzają to kolejne słowa z wykładu generała Gierasimowa: „Zwiększa się rola mobilnych kombinowanych zgrupowań wojsk, działajacych w jednolitej wywiadowczo-informacyjnej przestrzeni, dzięki wykorzystaniu nowych możliwości systemów zarzadzania i zabezpieczenia". ${ }^{9}$

Zdaniem W. Gierasimowa: „Wojskowe działania staja się bardziej dynamiczne, aktywne i efektywne. Znikaja taktyczne i operacyjne pauzy, które przeciwnik mógtby wykorzystać. Nowe informacyjne technologie pozwolity znaczaco zmniejszyć przestrzenny, czasowy i informacyjny dystans między wojskiem a organami wtadzy. Frontalne starcia wielkich zgrupowań wojsk na poziomie strategicznym i operacyjnym stopniowo odchodza w przeszłośc ć" ${ }^{60}$ Rosyjski generał w opublikowanym artykule w specjalistycznym piśmie „Wojenno-promyszliewyj Kurier” dokonuje też, w sposób pośredni bardzo dobrej charakterystyki działań prowadzonych na wschodniej Ukrainie: „Bezkontaktowe, na dystans, oddziatywanie na przeciwnika staje się głównym sposobem osiagnięcia celów walki i operacji. Pokonanie jego obiektów odbywa się na całej głębokości terytorium. Zacieraja się różnice między strategicznym, operacyjnym i taktycznym poziomem, między działaniami ofensywnymi i obronnymi”. ${ }^{61}$ Jednym z nowych zadań Sztabu było opracowanie „Planu obrony Federacji Rosyjskiej”. Zawiera on kompleks powiązanych wzajemnie dokumentów planowania wojennego dla całej wojskowej organizacji państwa. Taki plan był opracowany przez Sztab Generalny wspólnie z organami federalnymi władzy wykonawczej i zatwierdzony przez prezydenta Federacji Rosyjskiej w styczniu ubiegłego roku. A zatem, według zacytowanych wyżej słów rosyjskiego generała, początków planu destabilizacji Ukrainy w stylu, który widzimy od miesięcy na Krymie i w Donbasie, można doszukać się już w styczniu 2012 r.

W czerwcu 2015 roku pojawiły się scenariusze, opracowane przez amerykańską agencję analityczno-wywiadowczą ,Stratfor”, dotyczące potencjalnego rozwoju wydarzeń na wschodniej Ukrainie w kontekście neoimperialnej strategii działań militarnych podejmowanych przez prorosyjskie siły separatystyczne wspierane przez żołnierzy armii rosyjskiej. Scenariusze te wpisują się we wspomniana wyżej strategię „zbierania ziem”. Wariant pierwszy, nazwany „Land bridge scenario” zakłada możliwość przejęcia przez separatystów takich terytoriów, które umożliwiłyby utworzenie korytarza lądowego łączącego (poprzez Doniecką i Ługańską Republikę Ludową) terytorium Federacji Rosyjskiej z Krymem. Chodzi tu przed wszystkim o takie poszerzenie frontu toczących się walk, aby zapewnić sobie możliwość dostarczania wody pitnej dla Krymu z Dniepru i innych rzek znajdujących się na tych terenach. ${ }^{6}$ Poniżej przedstawiona mapa ilustruje graficznie ten wariant:

\footnotetext{
${ }^{59}$ Ibidem.

${ }^{60}$ Cyt. za: W. Gierasimow, Rol gienieralnawo sztaba w organizacji oborony strany...

${ }^{61}$ Ibidem.

${ }^{62}$ A. Dechtiarenko, Try glawnych scenarja wtarżenia Rassiji w Ukrainu: dannyje czastnoj razwietki SSzA, http://apostrophe.com.ua/article/politics/2015-06-21/shest-stsenariev-vtorjeniya-rossii-v-ukrainu-dannyie-chastnoy-razvedki-ssha/1871 [odczyt: 23.06.2015].
} 
LAND BRIDGE SCENARIO

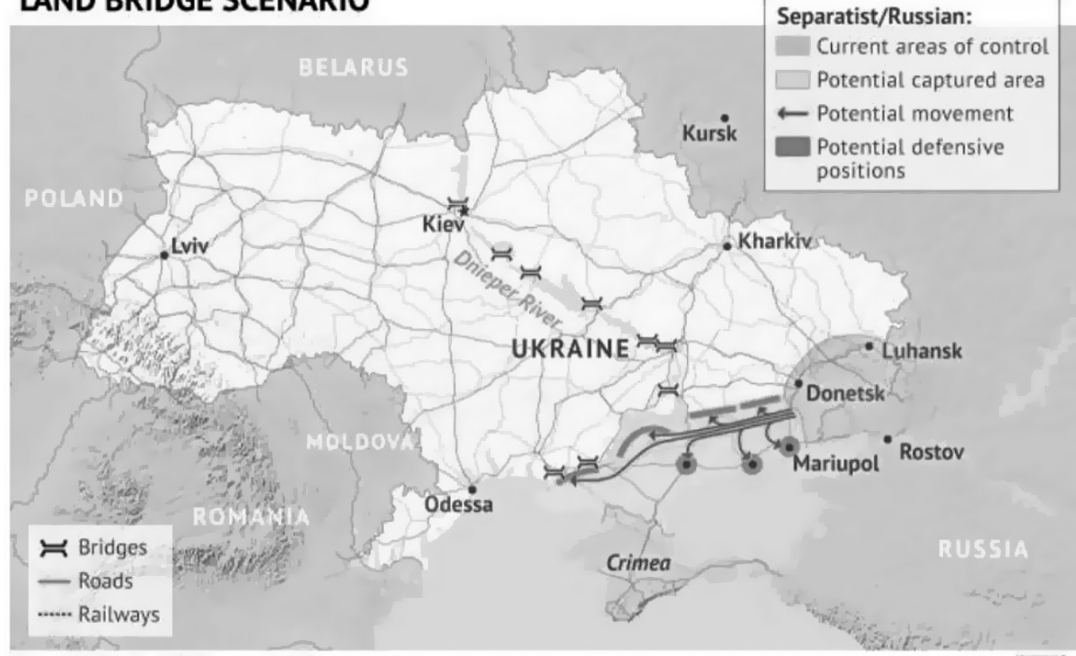

Copyright Stratfor 2015 www.stratfor.com

Źródło: Prywatna rozwytka SSzA opublikowała 3 scenarii zachoplennja Ukrainy Putinym, http://www.pravda.com.ua/news/2015/06/22/7072056/ [odczyt 22.06.2015]

Wariant drugi, pod nazwą: „Coastal scenario” uwzględnia możliwość stworzenia korytarza lądowego aż do Naddniestrza, czyli de facto opanowanie całego północnego wybrzeża Morza Czarnego łącznie z Odessą. Z geostrategicznego punktu widzenia dla Federacji Rosyjskiej byłby to wariant bardzo korzystny, łączący praktycznie w jedną całość dwa ,separatystyczne obszary” - Naddniestrza

COASTAL SCENARIO

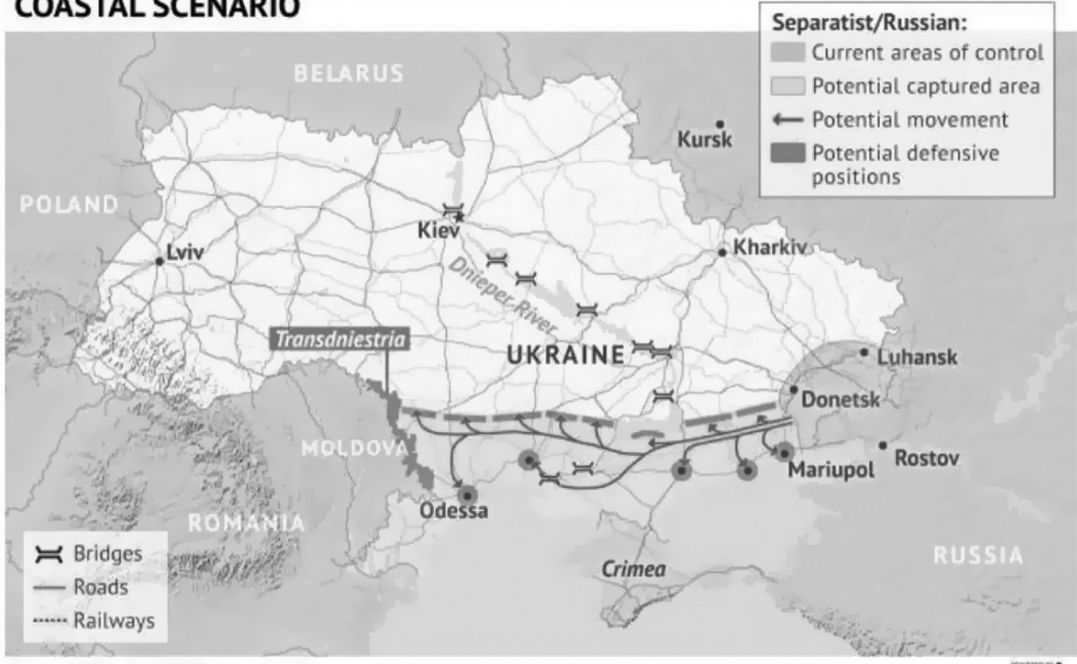

Copyright Stratfor 2015 www.stratfor.com

Źródło: Prywatna rozwytka SSza opublikowała 3 scenarii zachoplennja Ukrainy Putinym, http://www.pravda.com.ua/news/2015/06/22/7072056/ [odczyt 22.06.2015] 
oraz tzw. „Małorosji”. Zdaniem amerykańskich ekspertów, w tym celu należałoby użyć ok. 40-60 tys. żołnierzy, których zadaniem byłoby przemieszczenie się ponad $645 \mathrm{~km}$ w kierunku południowo-zachodnim i przejęcie kontroli na obszarze ponad 103 tys. $\mathrm{km}^{2}{ }^{63}$ Mogłoby to zając ok. 28 dni. Dodatkowo eksperci ocenili, że do utrzymania kontroli nad miejscową ludnością (ponad $6 \mathrm{mln}$ osób) potrzebne byłoby wsparcie ok. 13,2 do nawet 120 tys. żołnierzy. ${ }^{64}$

Trzeci scenariusz nazwany „Eastern Ukraine scenario” odnosi się do oderwania wschodniej części Ukrainy od reszty państwa i stworzenie nowego podmiotu w stosunkach międzynarodowych. Wymagałoby to przejęcia i opanowania terytorium o powierzchni 222,740 tys. $\mathrm{km}^{2}$, przesunięcia działań militarnych w kierunku południowo-zachodnim o ok. $402 \mathrm{~km}$, co wymagałoby zaangażowania od $91 \mathrm{do}$ 135 tys. żołnierzy ${ }^{65}$ Dodatkowo do utrzymania kontroli nad miejscową ludnością (13 mln osób) potrzebne byłoby wsparcie ok. 28 do nawet 260 tys. żołnierzy. ${ }^{66}$ Oznaczałoby to w praktyce konieczność zaangażowania w ww. operację znakomitej większości sił wojsk lądowych armii rosyjskiej, co rzecz jasna oznaczałoby jawne włączenie się Rosji do poważnego naruszenia integralności terytorialnej Ukrainy i sposowodowałoby ostrą reakcję państw zachodnich.

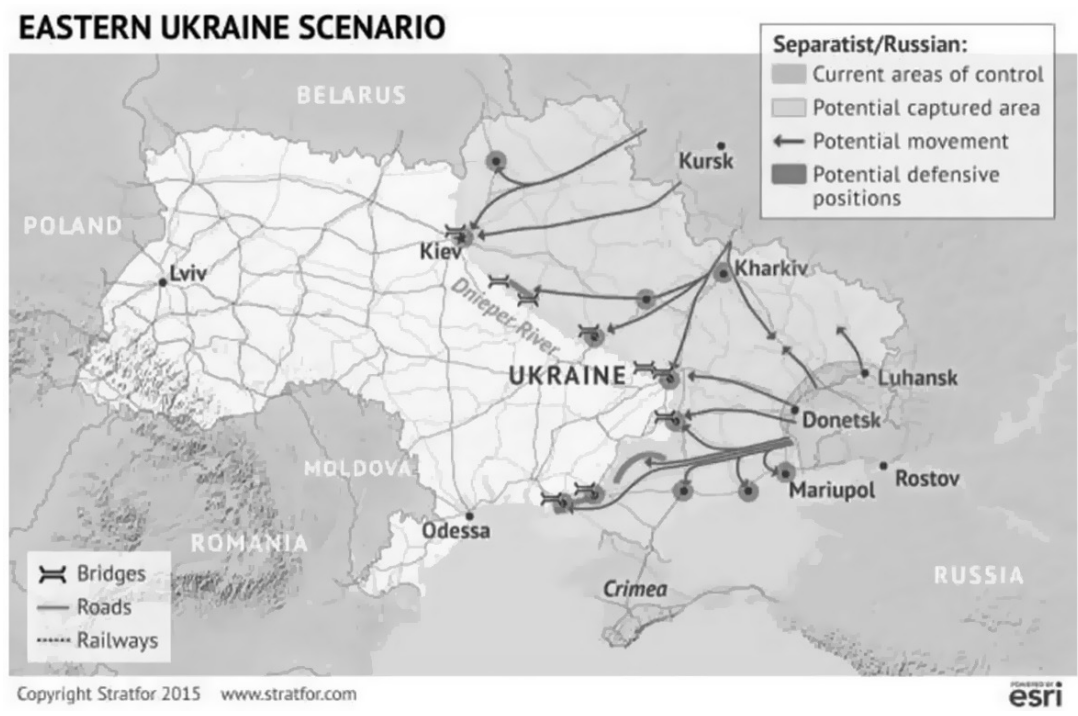

Źródło: Prywatna rozwytka SSza opublikowała 3 scenarii zachoplennja Ukrainy Putinym, http://www.pravda.com.ua/news/2015/06/22/7072056/ [odczyt 22.06.2015]

\section{${ }^{63}$ Ibidem}

${ }^{64}$ Prywatna rozwytka SSza opublikowata 3 scenarii zachoplennja Ukrainy Putinym, http:// www.pravda.com.ua/news/2015/06/22/7072056/

${ }^{65}$ A. Dechtiarenko, Try gławnych scenarja wtarżenia Rassiji w Ukrainu...

${ }^{66}$ Prywatna rozwytka SSza opublikowata 3 scenarii... 
Reasumując rozważania podjęte w niniejszym artykule należy stwierdzić, iż zjawisko wojny hybrydowej w drugiej dekadzie XXI wieku przedstawia się jako idealna wariant strategiczny dla zdestabilizowania innego kraju przez państwo, które z różnych względów nie chce angażować się w otwarty konflikt zbrojny. Oficjalne ogłoszenie wojny wiąże się z o wiele poważniejszymi sankcjami międzynarodowymi oraz alienacją na arenie międzynarodowej niż wielowymiarowe podkopywanie stabilności atakowanego kraju. Działania podejmowane przez Rosję na terytorium Ukrainy zmierzają $\mathrm{w}$ dłuższej perspektywie do podporządkowania sobie tego państwa oraz uniemożliwienie mu integracji z zachodnioeuropejskimi strukturami militarnymi i politycznymi. W tym miejscu można przytoczyć słowa Zbigniewa Brzezińskiego, mówiące o tym że geografia bywa czasem największym przekleństwem kraju. Ukraina, jako państwo piwotalne, zajmujące znaczną część obszaru wschodnioeuropejskiego, stanowiącego w myśl koncepcji Halforda Mac Kindera Heartland umożliwiający zdobycie panowania nad Wyspą Świata, zawsze będzie stała na drodze Rosji do osiągnięcia imperialnej pozycji i dlatego też Rosja będzie dążyła do kontrolowania tego państwa w różnorodny sposób. Dzięki nowoczesnym technologiom, propagandzie, destabilizacji infrastruktury informatycznej oraz poprzez konwencjonalne ataki militarne, Federacja Rosyjska dokonuje świadomej i systematycznej implementacji swych założeń strategicznych, mających na celu dezintegrację kraju położonego nad Dnieprem.

Wojna hybrydowa staje się zatem we współczesnych warunkach jednym z największych zagrożeń bezpieczeństwa międzynarodowego - o czym uświadamiają nam informacje napływające z Ukrainy. Świat zachodni starał się przez pewien czas przyglądać tej wojnie z bezpiecznej odległości, jednak wizja rozszerzenia się jej skutków poza obszar postradziecki niejako wymusza podejmowanie coraz bardziej konkretnych działań, mających na celu zahamowanie neoimperialnych „zapędów” Federacji Rosyjskiej.

\title{
HYBRID WAR AS THE POLITICAL STRATEGY OF NEO-IMPERIAL EXPANSIONISM OF RUSSIAN FEDERATION FACING UKRAINE
}

\begin{abstract}
The theme of the article is to analyze the specifics of the phenomenon of hybrid war as a method of operation used in case of a conflict between two entities in international relations. The dominant party in the conflict, using hybrid warfare wants most of all to get relatively sustainable advantage over the opponent, in order to achieve a certain position. In case of conflict in eastern Ukraine's strategic goal of the Russian Federation to emphasize the importance of the state in the post-Soviet space. Hybridization can therefore apply to both belligerent (state, non-state entity, irregular armed group), as well as the conflict (particularly the battlefield), its origins and the nature, ie. ecosystem conflict.
\end{abstract}

Key words: Russian Federation, Ukraine, international conflicts, hybrid wars, international security 